\title{
Serial Verb Constructions in Sikkanese
}

\author{
Ni Luh Ketut Mas Indrawati \\ English Department, Faculty of Arts, Udayana University, Denpasar, Indonesia \\ Ni Made Suryati \\ English Department, Faculty of Arts, Udayana University, Denpasar, Indonesia \\ Ida Ayu Made Puspani \\ English Department, Faculty of Arts, Udayana University, Denpasar, Indonesia
}

\begin{abstract}
Serial verb construction (hereafter abbreviated as SVC) is a construction consisting of more than one verbs without any overt markers of coordinator or subordinator. SVC is a common phenomenon in isolating languages which lack morphological markers for syntactic processes. Sikka language (Sikkanese belongs to isolating language with SVO type and it does not have diathesis. This research attempts to analyse the typological characteristics of Sikkanese SVCs which cover: prosodic/phonological, morpho-syntactic, and semantic features of SVCs in Sikkanese. The theory adopted in this research is typological theory which is applied by Van Stedent and Ger Reesink (2008) in analysing SVCs in East-Nusantara languages. The prosodic characteristic shows that Sikkanese SVCs fell under one intonation contour, similar to the intonation of a single clause and without being separated by a pause; morphosyntactically SVCs in Sikkanese could be categorised into independent and some belong to co-dependent type without any morphological markers; and symantically they could be analysed into: (1) motion; (2) direction, (3) manner; (4) instrument; (5) purpose; (6) progressive; (7) modality
\end{abstract}

Index Terms-SVC, typology, phonology, morpho-syntax, and semantics

\section{INTRODUCTION}

Sikkanese is a regional language in Sikka District, on the island of Flores belonging to the Province of East Nusa Tenggara, in Indonesia. According to Fernandez (1996) and Sedeng, (2000) this language is grouped into AmbonTimorese languages, and is estimated to have approximately 251 and 125 speakers. Sikkanese is classified into two geographical dialects, namely: Sikkanese dialect in West Sikka and Krowe / Kangae / Tna Ali dialect, in East Sikka (Fernandez, 1996, p. 36). In addition to Sikkanese, in Sikka District, there are other minor languages: Bajo and Bugis languages used by migrants from Sulawesi, and Paluqe language used on Paluqe Island, besides Indonesian as national language. Sikkanese is used by its speakers in everyday life, which deals with customs, agriculture, commerce, and religious matters. In addition, Sikkanese is also used as a lingua franca during the transition of children learning Indonesian as a national language. Sikkanese is also used as a means of disseminating information on the results of national development in rural areas as a companion of Indonesian language (Sedeng, 2000, p. 2).

In the explanation of the 1945 Constitution, Chapter XV, Article 36, it is stated that the local languages still used as a means of communication by the local community are nurtured and maintained by the state. The guidance is based on the fact that regional languages are parts of Indonesian culture. One form of guidance and preservation of regional languages is the study of all linguistic aspects of the languages in Indonesia (Halim, 1976: 21).

Associated with the preservation of Sikkanese in the form of research, today's research on Sikkanese has been done previously. These studies lead to the study of geographical dialects, historical linguistic studies, and several studies related to the phonological, adaptation and expression of Sikkanese customs. In general, Sikkanese research related to the micro aspect is based on structural theory and so far no one has specifically examined the construction of Sikkanese verbs.

Serial verb construction (SVC) is a clause consisting of more than one verb without any markers of subordinator or coordinator. SVC is a common phenomenon in isolating languages that have no morphological markers for syntactic processes. Sedeng (2000) revealed that Sikkanese was classified into isolating language with SVO-type, and lacked passive diathesis. This language has a very minimal morphological process, and grammatical concepts to be expressed, through separate lexicon. It is the limitations of this morphological process that gave rise to the construction of serial verbs as seen in the following examples. 


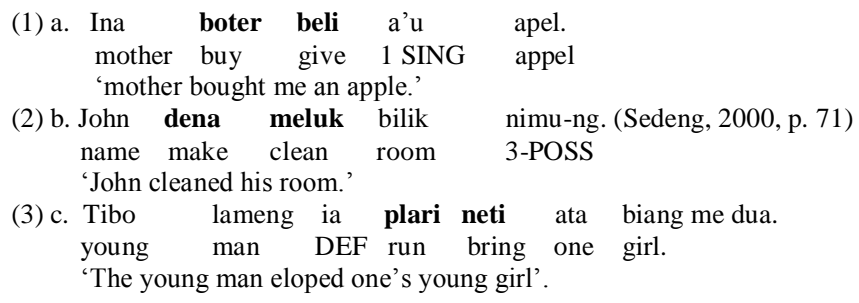

From the three examples (1a-c), it can be said that what is conveyed in English using one verb is expressed by two main verbs in Sikkaness: boter "buy", beli "give", dena" make " meluk" clean ", plari "elope" "neti" bring ". The verbs in the SVC in the examples are the main verbs and can appear independently in one clause.

The SVC phenomenon seen in examples $1(\mathrm{a}-\mathrm{c})$ is very interesting to study and has been widely discussed in the literature (cf. Senft (2008), Aihkenvald (2006), Kroeger (2004), and Indrawati (2014). However, until now the concept of SVC is still interesting to be analyzed, because its characteristics are specific, depending on the language under study. Seeing this opportunity, on this occasion the researcher raised the topic of SVCs in Sikkanese, seen from its typological perspective and analysed their characteristics involving phonological, syntactic, and semantic characteristics.

\section{THEORY AND CONCEPT}

The theory applied in discussing Sikkanese SVC is the language typological approach proposed by Van Staden and Ger Reesink in Senft, eds. (2008) in their research entitled "Serial verb constructions in a linguistic area". They state that what is included in the criteria of serial verbs are all forms or constructions in which two or more verbs occur in a clause and none of the verbs is clearly and formally subordinate to the other. SVC often called as a complex predicate is essentially two terms syntactically and semantically similar, since the complex predicate refers to the notion of predicate which may be morphologically composed of a verb but its semantic impression is complex or composed of several verbs that are also complex in meaning. Baker (1997, p. 247) suggests that the term complex predicate refers to any complex predicate, semantically, syntactically, and morphologically. This means that the serialization of verbs is an integral part of the complex predicate.

Van Staden and Ger Reesink in Senft, eds.(2008, p. 22), stress that in SVC there is no conjunction, linkage, or "nonfinite" marker between the two verbs in the SVC, both verbs can stand alone in clauses outside SVC, the serial verbs form a single predicate in a clause, and they have the characteristic of sharing arguments. Phonologically SVCs have single intonation, the verbs in series cannot be separated by a pause.

Morphosyntactically, Van Staden and Ger Reesink differentiate SVCs into four, groups namely: independent SVC, dependent, co-dependent SVC, and complex SVC.

Independent SVC refers to SVCs of which all verbs in the constructions are morphologically inflected, as those of a single verb in a simple clause.; dependent SVC is defined as a construction that is only one of its verbs being inflected, while the other is in the form with no affixes. Co-dependent SVC, in this SVC the serial verbs have the characteristics of argument sharing and parts of the constructions are interdependent. The first clause's Object is the Subject of the second clause schematically, the co-dependent SVC can be described as follows:

(NP) V NPobj=su V (NP)

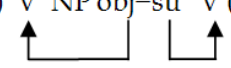

Van Staden noted that in East Nusantara languages, co-dependent constructions involve fully inflected verbs. For example, consider the following Taba language.

(1) $\mathrm{N}=$ babas welik $\mathrm{n}=$ mot do 3SG=bite pig 3SG=dieREAL

'It bit the pig dead.' (Bowden ,2001a, p.311 in Senft, eds, 2008,p.25).

Complex SVC: in this type, two or more verbs have a set of affixes: the prefix is attached to the first verb and the suffix to the last verb in the series. This type of SVC is very similar to composition. For example, consider the Inanwatan language quoted from Van Stadent and Ger Reesink (Senft, eds., 2008, p. 27) below.

(2) Me-de-wo-re

3:SU-go:across-come-PAST

'They came across'.

Seen from the meaning of SVCs, Van Stadent Ger Reesink finds meanings: motion, direction , changing conditions, and instrument, manner, aspects and moods.

\section{Methodology}

The method applied in this study involved four steps they were; data source, methods and techniques of providing data, methods and techniques of analyzing data, and methods and techniques of presenting the results of data analysis. Data source; The Sikkanese used as a population of data sources was the Sikkanese spoken throughout Sikka District. Data source in this research consisted of primary and secondary data source. Primary data sources were from native 
speakers obtained both from speakers used as informants and people who were not used as informants. The data sought were in the forms of sentences used in folklores, customs, beliefs, and aspects of social and cultural life of the community. Secondary data were obtained from the results of existing research, and these data were used as comparisons.

Methods and techniques of providing data; this research is considered as field research, it means that the researchers directly went into the field to obtain data. This method is considered higher in academic degrees; in addition researchers could also directly ask the things that were considered important. The methods applied in collecting the data were observation and interview by means of recording and note-taking. Methods and techniques of analyzing data; the data that had been collected were descriptive-qualitatively analysed based on the theory of language typology. Methods and techniques of presenting the results of data analysis; the data that had been analysed were informally presented based on the characteristics of the Sikkanese SVCs

\section{Discussion}

The language typology approach is an approach which aims at grouping language according to its structural features. This approach assumes that languages can be compared to each other according to their structure, and the other assumption is that there are differences between languages. In other words, language has universal features and specific characteristics that distinguish one language from another.

\section{A. Phonological Characteristics of Sikkanese SVC}

As described above, phonologically SVCs have single intonations without being separated by pauses. Sikkanese SVC can be said to fall into one intonation similar to the intonations in single clauses, there is no pause between one verb to the other. This supports what is expressed by Aikhenvald and Dixon (2006) and other linguists who argue that SVC has the intonation characteristic of a single-verb clause and not the intonation of a series of clauses. It is also explained that in many languages the clause boundary is marked by the separation of intonation or pause whereas in SVC there is no pause between verbs forming SVC. It can be seen in the following data proved by using speech analyzer and spectrograph.

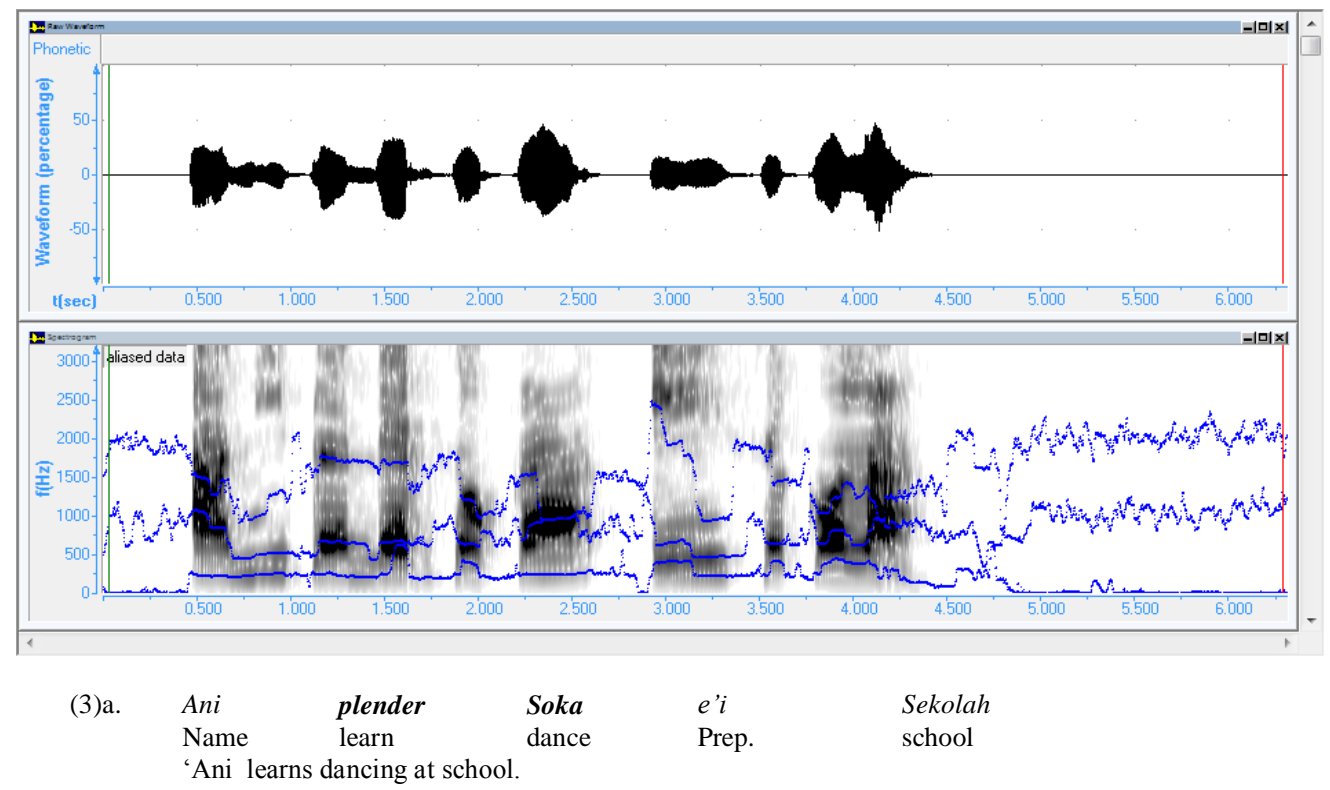




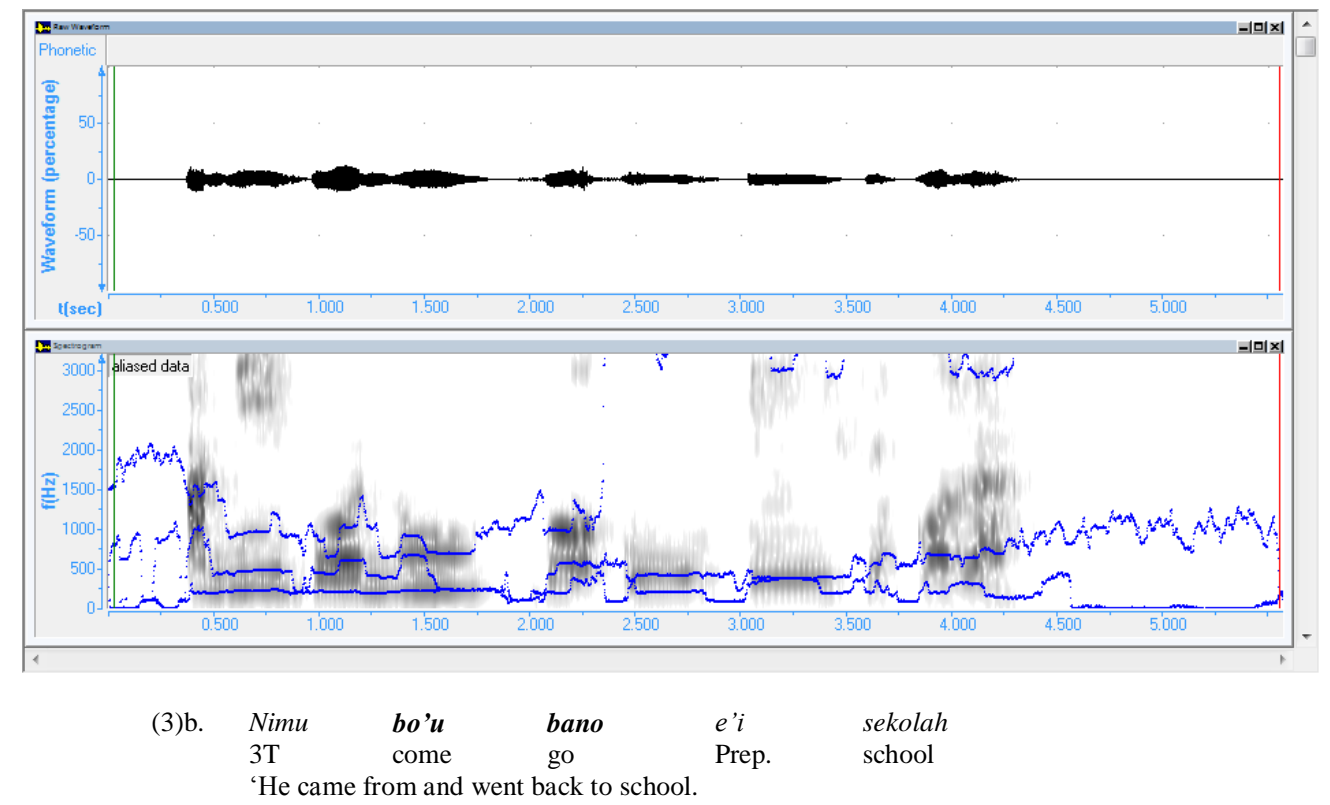

If the speech analyzer and its spectrophotograph are concerned, it appears that the verb bo'u bano 'come and go', between them there is a long distance indicating that there is a pause between bo' $u$ and bano. This is in contrast with data 4a. splender Soka 'learn dancing', there is no pause between splender and Soka, and in the spectrograph there is no long distantance.

\section{B. Morphosyntactic Characteristics of Sikkanese SVC}

Morphosyntactically Sikkanese SVCs consist of two types, namely (1) independent type and (2) co-dependent type. Both are outlined as follows.

The independent SVCs of Sikkanese

Sikkanese independent SVCs can be illustrated based on the following Sikkanese data;

$\begin{array}{llllll}\text { (4)a. } & \text { Robert } & \text { GEra } & \text { tutur } & \text { nora } & \text { Floren } \\ \text { Name } & & \text { Stand } & \text { speak } & \text { prep } & \text { Name } \\ \text { 'Robert } & & \text { stood } & \text { speaking } & \text { with } & \text { Floren'. } \\ \text { (4)b. } & \text { Ani } & \text { plender } & \text { Soka } & \text { E } & \text { sEkola } \\ & \text { Name } & \text { learn } & \text { dance } & \text { Prep. } & \text { School } \\ \text { 'Ani learns dancing at school'. } & & & \\ \text { (4)c. } & \text { Petrus } & \text { Bano } & \text { Plari } & \text { Sekolah } \\ & \text { Name } & \text { go } & \text { run } & \text { Prep. } & \text { school }\end{array}$

Data 5a consists of serial verbs, gEra tutur 'stand up speaking' (V1: gEra 'stand' and V2: tutur 'speak' ); data 3b, serial verbs plender soka 'learn to dance' (V1: plender 'learn' and V2; soka 'dance'); the verbs bano plari 'go run' (V1: bano 'go' and V2: plar i 'run'). Data 5(a-c) are said to be independent types because each verb can stand alone when used as a single-verb in a clause. It can be proved by the following data:

$\begin{array}{lllll}\text { (5)a. } & \begin{array}{l}\text { Robert } \\ \text { Name } \\ \text { 'Robert stood up with Floren'. }\end{array} & \begin{array}{l}\text { gEra } \\ \text { stand }\end{array} & \begin{array}{l}\text { nora } \\ \text { Prep. }\end{array} & \begin{array}{l}\text { Floren } \\ \text { Name }\end{array} \\ \text { (5)b. } & \begin{array}{l}\text { Robert } \\ \text { Name }\end{array} & \text { tutur } & \text { Nora } & \text { Floren. } \\ & \text { 'Robert } & \text { spoke with Floren'. } & \text { Prep } & \text { Name }\end{array}$

\section{Co-dependent Sikkanese SVCs.}

Co-dependent type of Sikkanese SVCs can be seen in the following data. 


\begin{tabular}{|c|c|c|c|c|c|c|}
\hline (6)a & $\begin{array}{l}\text { Matiu } \\
\text { Name }\end{array}$ & $\begin{array}{l}\text { tung } \\
\text { take }\end{array}$ & $\begin{array}{l}\text { inan } \\
\text { mother }\end{array}$ & $\begin{array}{l}\text { Obat } \\
\text { check up }\end{array}$ & $\begin{array}{l}e^{\prime} i \\
\text { prep }\end{array}$ & $\begin{array}{l}\text { Doctor } \\
\text { doctor }\end{array}$ \\
\hline & \multicolumn{6}{|c|}{ 'Matius took mother to check up to the doctor'. } \\
\hline (6)b. & $\begin{array}{l}A u \\
2 \mathrm{~T}\end{array}$ & $\begin{array}{l}\text { dEna } \\
\text { make }\end{array}$ & $\begin{array}{l}a^{\prime} u \\
1 \mathrm{~T}\end{array}$ & $\begin{array}{l}\text { Ela } \\
\text { fall }\end{array}$ & $\begin{array}{l}e^{\prime} i \\
\text { prep }\end{array}$ & $\begin{array}{l}A i \\
\text { tree }\end{array}$ \\
\hline (6)c. & $\begin{array}{l}\text { 'you m } \\
A^{\prime} u \\
1 \mathrm{~T}\end{array}$ & $\begin{array}{l}\text { me fall } \\
\text { pano } \\
\text { go }\end{array}$ & $\begin{array}{l}\text { n from t } \\
\text { sekola } \\
\text { school }\end{array}$ & $\begin{array}{l}\text { pe'. } \\
\text { pake } \\
\text { use }\end{array}$ & $\begin{array}{l}\text { sepeda } \\
\text { bike }\end{array}$ & \\
\hline
\end{tabular}

The SVC in data 7a, are tung 'take' (V1) and obat 'check up' (V2). Between these two verbs there is a noun 'mother'. The serial verbs in data $7 \mathrm{~b}$ are $d E n a$ 'make' (V1) and Ela' fall' (V2). Both verbs are interrupted by the pronoun, $a^{\prime} u$ ' me'. The SVC in data 7c is pano 'go' (V1) and Pake 'use' (V2). Both verbs are interrupted by a noun, sekolah 'school'. The three SVCs in 7 (a-c) are said to be co-dependent because the two verbs are related to each other, and the Object argument of the first verb is co-referrenced to the Subject argument of the second verb.

\section{The Semantic Characteristics of Sikkanese SVCs}

Kroeger (2004, p. 227) reveals that the verbs in the SVCs usually express single events, however since both verbs contribute to the meaning of the clauses therefore the resulting meaning will be more complex than the meaning of each individual verb. The diversity of meanings formed by the verbs in series such as: the meaning of instrument, manner, direction, and aspects.

an Staden and Ger Reesink in Senft, eds.(2008, p. 36) suggest that the meaning of SVCs is determined by a small group of verbs whose meanings can be generally identified and the overall constructions are categorized according to the group of these verbs. By following this way the meanings of Sikkanese SVCs can be described in the following data.

1 Motion

Verb movements such as: mai 'come', balong 'walk', belung 'leave' are mostly found as V1 in Sikkanese followed by another action performed by the same Agent expressed by V2. This construction indicates that the Agent moves in a certain direction to perform the event expressed by V2 (as the destination). Cross-linguistically, SVCs expressing motion is very common as noted by Durie (1997, p. 310):

"Every serializing languages I have encountered includes a category of motion serialisation, where a verb of motion is combined with some other verbs in such a way that the motion verb comes first and the moving argument is the Agent of the second verb". Sikkanese SVCs expressing motion can be seen in the following data:

\begin{tabular}{|c|c|c|c|c|}
\hline (7)a. & $\begin{array}{l}\text { Wue } \\
\text { Elder brother /sister }\end{array}$ & $\begin{array}{l}\text { mai } \\
\text { come }\end{array}$ & $\begin{array}{l}\text { tota } \\
\text { Look for }\end{array}$ & $\begin{array}{l}A^{\prime} \text { 'u } \\
\text { 1Sing }\end{array}$ \\
\hline \multicolumn{5}{|c|}{ 'Elder brother /sister came to look for me' } \\
\hline (7)b. & $\begin{array}{l}\text { Ina } \\
\text { mother }\end{array}$ & $\begin{array}{l}\text { mai } \\
\text { come }\end{array}$ & $\begin{array}{l}\text { neti } \\
\text { bring }\end{array}$ & $\begin{array}{l}m u ' u \\
\text { bananas }\end{array}$ \\
\hline
\end{tabular}

Data 8a and b showed that V1 mai 'come' (intransitive) is a motion verb. Mai, indicated that the Agent moved toward the speaker to show or perform the action expressed by V2, tota (as the purpose).

V2, tota 'looking for' (transitive) requires an Agent that is the person looking for and Patient or something to look for. In clauses 8a and b, wue 'elder brother /sister' as an Agent of mai (movement action), and also Agent for mai movement action with the aim of doing tota. In the data 8b, the agent of mai 'come' is the 'mother' who is also the Agent of neti 'take', V2 neti requires two arguments ie; Agent and Patient, Agent of neti action is ina 'mother' while the Patient is $m u ' u$ 'banana'. The agent moves toward the speaker with the purpose to perform the action expressed by V2 (neti) as the goal, or the Agent performs tota and neti actions by way (manner) of mai 'come'.

Data (8a-b), indicated that motion verbs as V1 of Sikkanese SVC had a relationship of purpose meaning or of manner. SVCs with motion V1 are very productive in Sikkanese

\section{Sikkanese SVCs with direction meanings}

Bair in Senft eds.( 2008, p.68) reveals that words indicating direction and space, such as seawards (direction otowards the sea), inland, above, and below are commonly found, both in Austronesian and non-Austronesian languages in the East Nusantara and Pacific. Van Staden and Ger Reesink in Senft, eds. (2008) suggest that a construction that reveals the direction semantic relationship is defined by V2 (direction verb) that indicates the direction or location of the movement or action event. Manners are shown by V1. SVCs expressing direction in Sikkaness are presented below:

$\begin{array}{llllll}\text { (8)a. } & \begin{array}{l}\text { Robert } \\ \text { Name }\end{array} & \text { Bano } & \text { le } & \text { Nalk } & \\ & \begin{array}{l}\text { 'Rabert walked to the east'. } \\ \text { 'Robst }\end{array} & & \\ \text { (8)b. } & \text { Wair } & \text { E } & \text { kran } & \text { beta } & \text { sira-wirang } \\ & \text { Water } & \text { Def } & \text { tap } & \text { drip } & \text { exit } \\ & \text { 'water dripped out'. } & & & \end{array}$


In data (9a-b) V2 le na 'to the east', and wira sensei 'exit' are verbs showing directions. These verbs are the main verbs in the SVC, while the other verbs are bano 'walking', and beta 'drip' are motion verbs which in the SVCs show manners semantic relation. The meaning of the relationship is bano le na 'le na by means of bano' ', and beta sira werang' sira werang by beta 'dripping way'.

Data (9a) shows that, V1 bano 'run' is an intransitive verb that requires a subject's argument, Robert, and le na is an intransitive verb that requires a subject argument. Subjects of V1 and V2 refer to the same noun, namely Robert. In data (9b), V1, beta 'drip' is an intransitive verb which requires a Subject argument, Wair 'water', and sira-wirang 'exit' is an intransitive verb that requires one subject argument which is in the clause referring to the subject of V1. So V1 and V2 also share the subject.

\section{Sikkanese SVCs expressing manners}

In SVCs expressing manners, one of their verbs reveals the manners of the actions expressed by the other verbs. Generally the verbs expressing manners follow their main verbs. Van Staden in Senft eds. (2008, p. 44). In Sikkanese SVCs expressing manner with intransitive verbs as V1, the manner was generally expressed by V2, except for the purpose of stressing the manners. It was also found in Sikkanese that SVCs with manner meanings could be constructed by intransitive V1 and V2, and V1 Intransitive and V2 transitive. These could be presented in the following data:

\begin{tabular}{|c|c|c|c|}
\hline \multirow[t]{2}{*}{ (9)a. } & $\begin{array}{l}\text { Rimu } \\
3 \text { pl. }\end{array}$ & $\begin{array}{l}\text { pano } \\
\text { walk }\end{array}$ & $\begin{array}{l}\text { hama-hama } \\
\text { Together }\end{array}$ \\
\hline & \multicolumn{3}{|c|}{ 'They walked together' } \\
\hline (9)b. & $\begin{array}{l}\text { Tatik } \\
\text { Name }\end{array}$ & $\begin{array}{l}\text { plari } \\
\text { run }\end{array}$ & $\begin{array}{l}\text { ropo-ropo } \\
\text { Rush }\end{array}$ \\
\hline
\end{tabular}

In data 10a., V1, pano 'walk' is an intransitive verb, and V2, hama hama 'together' is also an intransitive verb. As intransitive verbs both require subject arguments that semantically act as Agents. In clause 10a, rimu 'they' is the subject of V1 and also the subject of V2. In other words, the subject of V2 is coreferrenced with the subject of V1, pano hama hama 'walked together' means walking by means of hama hama 'together'. Thus, V1 is the main verb expressing action, whereas V2 expresseses the way how the action expressed by V1 is done. In data 10b., V1, plari 'run' is an intransitive verb, V2, ropo-ropo 'rush' is also an intransitive verbs. As intransitive verbs both require subject arguments that semantically act as Agents. In clause 10b., Tatik is the subject of V1 and also the subject of V2. Therefore, the subject of V2 is co-referrenced with the Subject of V1. Plari ropo-ropo means running by way of ropo-ropo. Thus, V1 is the main verb expressing action, whereas V2 expresses the way how the action expressed by V1 is caried out.

Sikkanese SVCs of which meaning expresses manners with V1 intransitive verbs and V2 transitive verbs can be presented in the following data:

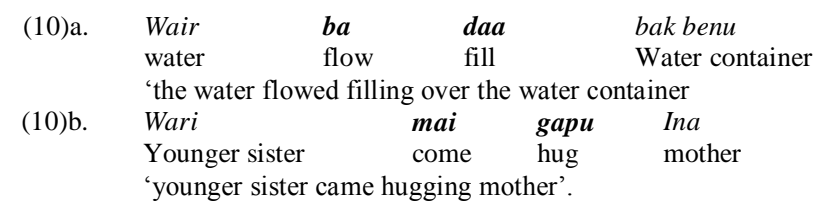

In data 11a and 11b, V1, ba 'flow', and mai 'come' are intransitive verbs. Meanwhile, daa 'fill ', and gapu' hug 'are transitive verbs. As an intransitive verb V1 needs a subject argument that acts as an Agent. In data 11(a-b), the subject argument of $b a$ 'flow' is wair 'water', and mai, wari 'sister '. Meanwhile, the V2 of the two SVCs are transitive verbs which require two arguments, namely the Subject argument as Agent and the Object argument as Patient. The Subject Argument of V2 is aligned with the Subject argument of V1. The Object argument of V2 in 11a is bak benu 'water container'and in $11 \mathrm{~b}$, the Object argument is ina 'mother'. In both data the manner meanings are expressed by V2. Semantically, baa daa has the meaning of ba 'flowing' by means of daa 'fill', and mai gapu 'come by hugging'.

\section{Sikkanese SVCs with instrument meaning}

SVCs with instrument meaning are the SVCs of which one of their verbs requires the instrument used to perform the actions expressed by the other verb. In Sikkanese SVC there is one verb that is the verb paket 'use' which is used as V2 to convey instrument of doing the action denoted by V1. This can be seen in the following data:

\begin{tabular}{|c|c|c|c|c|}
\hline \multirow[t]{2}{*}{ (11)a } & $\begin{array}{l}\text { Wari } \\
\text { younger }\end{array}$ & $\begin{array}{l}\text { pesiar } \\
\text { travel }\end{array}$ & $\begin{array}{l}\text { paket } \\
\text { use }\end{array}$ & $\begin{array}{l}\text { Bis } \\
\text { Bus }\end{array}$ \\
\hline & Younger & travele & bus & \\
\hline (11)b & $\begin{array}{l}\text { Ina } \\
\text { Mother }\end{array}$ & $\begin{array}{l}\text { bano } \\
\text { exit }\end{array}$ & $\begin{array}{l}\text { Paket } \\
\text { use }\end{array}$ & $\begin{array}{l}\text { Dokar } \\
\text { horse cart }\end{array}$ \\
\hline
\end{tabular}

Data 12a-b show that the verb, paket 'use', V2, have instrument meaning with transitive verbs that are collocated with verbs occupying V1 which behave as the main verbs. V2, paket on these SVCs behave like adverbial of instruments and the canonical structure of the adverb in the Sikkanese clause is after the verb. As an intransitive verb, $\mathrm{V} 1$ requires subject argument that acts as an Agent. In 12a-b, subject arguments of the verb pesiar is wari, and from 
bano, ina. Meanwhile, V2, the transitive verbs require two arguments, namely the Subject argument as Agent and the Object's argument as Patient. The Subject Argument of V2 is co-referrenced with the Subject arguments of V1, whereas the Object argument of V2, packet is bis 'bus (12a) and dokar data (12b). In data 12a-b the meaning of the instrument is expressed by V2. Semantically, pesiar paket has the meaning of pesiar 'traveling' and bano paket means bano by instrument; horse cart.

\section{Sikkanese SVCs with purpose meaning}

SVC with meaning relation of purpose is an SVC of which one of its verbs indicates a goal to achieve the objective of the action expressed by the other verbs. In Sikkanese there is a verb that can be used to express the meaning, ie dena 'make'. It can be seen in the following data.

\begin{tabular}{|c|c|c|c|c|}
\hline (12)a. & $\begin{array}{l}\text { Ina } \\
\text { mother }\end{array}$ & $\begin{array}{l}\text { hena } \\
\text { make }\end{array}$ & $\begin{array}{l}\text { Jajan } \\
\text { cake }\end{array}$ & $\begin{array}{l}\text { dena } \\
\text { make }\end{array}$ \\
\hline (12)b. & $\begin{array}{l}\text { Mother } \\
\text { Karti } \\
\text { Name }\end{array}$ & $\begin{array}{l}\text { cake to } \\
\text { hena } \\
\text { make }\end{array}$ & $\begin{array}{l}\text { Мии } \\
\text { fried banana }\end{array}$ & $\begin{array}{l}\text { dena } \\
\text { make }\end{array}$ \\
\hline
\end{tabular}

Data 13a-b indicate that V1, hena 'make' is a transitive verb requiring an object argument in this case jajan 'cake', data 13a, and тии 'fried banana' for data 13b. V2, dena (with the actual meaning make) which is in non-serialized language equal to preposition to or for is specifically used to express the purpose of the action denoted by V1.

\section{6 .Sikkanese SVCs with progressive meaning}

The progressive meaning can be expressed through Sikkanese SVCs with V1 of posture or motion verbs. This supports what is expressed by Aikhenvald and Dixon (2006, p. 23) that the verb of motion or posture verb can be used to express the meaning of progressive or continuous. In Sikkanese SVCs, these motion verbs usually fill V1, as seen in data $14 \mathrm{a}-\mathrm{b}$

\begin{tabular}{|c|c|c|c|c|}
\hline (13)a. & $\begin{array}{l}\text { Rimu } \\
\text { 3P1 }\end{array}$ & $\begin{array}{l}\text { Era } \\
\text { stand }\end{array}$ & $\begin{array}{l}\text { himo } \\
\text { look }\end{array}$ & $\begin{array}{l}a^{\prime} u \\
\text { 1Sing }\end{array}$ \\
\hline & 'They & lookin & & \\
\hline (13)b. & Pino & jano & boter & Buku \\
\hline & Name & walk & buy & Book \\
\hline & 'Pino & buyir & ok' & \\
\hline
\end{tabular}

Data 14a-b indicate that the V1 era 'stand', and jano 'walk' have meaning relations that the activities expressed by V2 (himo 'look/see', boter 'buy' ) are in progress. Both activities in V2s are still in process and have not been finished.

\section{Sikkanese SVCs with modal meaning}

Some verbs such as mogang 'ask' and ga? i' want or will' can be the V1 in Sikkanese SVCs and form a meaningful relationship of modalities to the activities expressed by V2. The data in 15a. and 15b illustrate this;

\begin{tabular}{|c|c|c|c|c|c|}
\hline (14)a. & $\begin{array}{l}\text { Rimu } \\
\text { 3Pl }\end{array}$ & & & $\begin{array}{l}\text { hantar ha } \\
\text { Sing }\end{array}$ & \\
\hline & 'He wo & ing to & & & \\
\hline (14)b. & $\begin{array}{l}\text { Riko } \\
\text { Name }\end{array}$ & $\begin{array}{l}g a ? \boldsymbol{i} \\
\text { want }\end{array}$ & $\begin{array}{l}\text { tata } \\
\text { know }\end{array}$ & $\begin{array}{l}\text { raita } \\
\text { house }\end{array}$ & $\begin{array}{l}\text { Oring } \\
1 \text { Sing }\end{array}$ \\
\hline
\end{tabular}

In data 15a., V1 mogang 'will' and V2 hantar hama-hama 'sing' are both active-intransitive form so that their subject arguments functioning as Agents are co-referenced. Meanwhile, in data 15b, V1 ga? $i$ 'want' and V2 tata 'know' are in the active-transitive forms. They both have two arguments, namely Subject arguments and Object arguments. The subject arguments of V2 is co-referenced with the Subject arguments of V1 that is Rico, meanwhile the Object argument of $\mathrm{V} 1$ is the complement clause,

tata raita Oring 'know my house' and the Object argument of V2 israita oring 'rumah saya'.

\section{CONCLUSION}

Based on the analysis on the phonological, morphosyntactic, and semantic features of the Sikkanese SVCs it could be concluded that: The phonological characteristics of Sikkanese SVCs showed that Sikkanese SVCs had single intonations, similar to the intonation in single clauses and were inseparable by pause. Mophosyntactically, SVCs in Sikkanese could be classified into independent types and some could be classified as co-dependent types. Semantically, Sikkanese SVCs had meaning relations of motion, purpose, direction, instrument, progressive, and modal.

\section{REFERENCES}

[1] Aikhenvald, Alexandra. (2006). Serial verb contruction in typological perspective in Alexandra Aikhenvald and Robert M.W. Dixon, eds., Serial verb contructions : a cross-linguistic typology. Oxford: Oxford Universty Press. 1-87. 
[2] Baker, Mark C. (1997). Complex Predicates and Agreement in Polysynthetic Languages. In Alex Alsina, Joan Bresnan, dan Peter Sells (ed.). Complex Predicates. Stanford, California. 247-288.

[3] Bohnemeyer, Jurgen. (1999). Event representation: some primordial soup for the evolution of a research project on event representation in language and cognition. $2^{\text {nd }}$ strongly revised draft November 11, 1999, Nijmegen: Mimeo. Books.

[4] Durie, Mark. (1997). Grammatical Structures in Verb Serialization. Dalam Alsina Alex, Joan Bresnan, and Peter Sells (Ed.). Complex Predicates. 289 - 354. Stanford, California: CSLI

[5] Fernandez, Inyo Yos. (1996). Relasi Historis Kekerabatan Bahasa Flores: Kajian Linguistik Historis Komparatif terhadap embilan Bahasa di Flores.Jakarta: Penerbit Nusa Indah.

[6] Halim, Amran (ed.). (1976). Politik Bahasa Nasional Jilid 1. Jakarta: Pusat Pembinaan dan Pengembangan Bahasa.

[7] Indrawati, Ni Luh Ketut Mas. (2014). Typological Perspective of the Balinese Serial Verb Constructions. Australia: AsiaPasific Linguistics college of Asia and Pacifice, The Australian National University.

[8] Kroeger, Paul R. (2004). Analyzing Syntax: A Lexical - Functional Approach. Cambridge: Cambridge University Press.

[9] Sedeng, I Nyoman. (2000). Predikat Kompleks dan Relasi Gramatikal Bahasa Sikka (tesis). Denpasar: Program Pascasarjana Universitas Udayana.

[10] Sedeng, I Nyoman. (2007). Morfosintaksis Bahasa Bali Dialek Sembiran. Analisis Tatabahasa Peran dan Acuan (disertasi) Denpasar: Program Pascasarjana Universitas Udayana Denpasar.

[11] Senft, Gunter. (2008). Serial Verb Construction in Austronesian and Papuan Languages. Australia: Pacific Linguistics Research School of Pacific and Asian Studies.

[12] Talmy, Leonard. (2000). Toward a Cognitive Semantics. 2 volumes. Cambridge: Cambridge University Press.

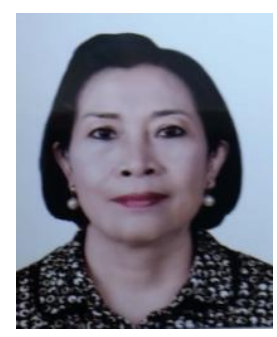

Ni Luh Ketut Mas Indrawati was born at Tabanan, Bali, Indonesia, on October $10^{\text {th }} 1959$. She obtained her M.A degree in Sydney University in 1995, her Dr. degree in Udayana University in 2012. She has been a lecturer at English Department Faculty of Arts, Udayana University since 1985. Her research interest includes syntax, translation, morphology, and TEFL. Some of her scientific articles are published on International and accredited journals entitled: Typological Perspective of the Balinese Serial Verb Constructions, Aspectual Verbs in Balinese, Manner Adjunct in English and the Implication in the Teaching EFL, and The Balinese SVCs and Their Equivalences in English.

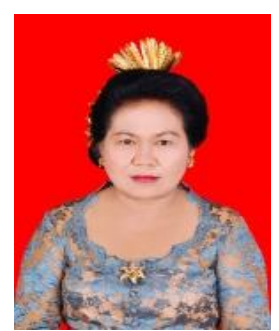

Ni Made Suryati was born in Karangasem Bali Indonesia on $31^{\text {st }}$ of December 1960. She received her Dr. degree in Linguistics from Udayana University in 2012. She is currently a lecturer at Balinese Department Faculty of Arts Udayana University. Her research interest includes semantics, syntax and pragmatics. Some scientific articles are published on accredited journals namely: Personal Deixis Variation in Balinese: A Dialectology Study and Oposisi Makna Dalam Bahasa Lio.

Dr. Ni Made Suryati ia a member of APBL (Association of Local Language) and MLI (Indonesian Linguistic Society)

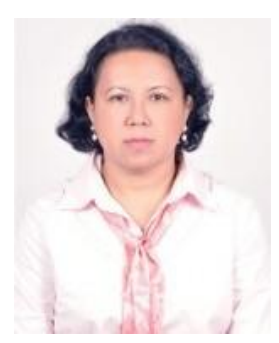

Ida Ayu Made Puspani was born in Marga Tabanan Bali Indonesia on September $16^{\text {th }} 1962$. She received her Dr. degree in linguistics from Udayana University in 2010. She is currently a lecturer at English Department Faculty of Arts, Udayana University. Her research interest includes translation, interpreting and morphology. Some scientific articles are published on accredited journals namely:Balinese Suffixes -an and in and Their Morphological Process, Court Interpreting at Denpasar Court, and Identifying Meaning Components in Translation of Medical Terms from English into Indonesian :A Semantics Approach.

Dr. Ida Ayu Made Puspani is a member of HPI (Indonesian Translator Association and TEFLIN (Teacher of English Language in Indonesia) 